JURNAL TEERNOSAINS

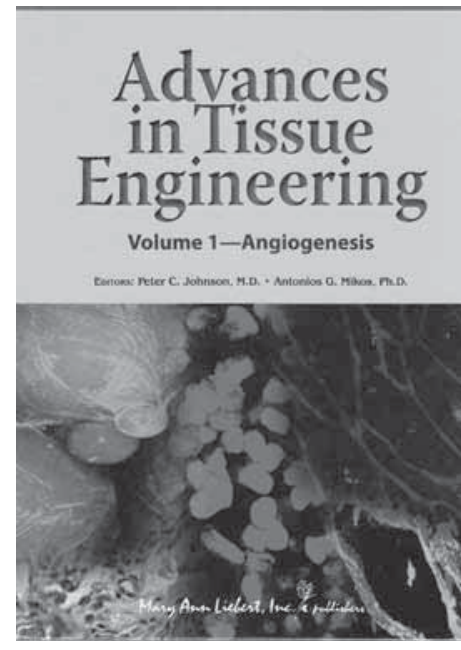

\title{
RESENSI MENUMBUHKAN NADI BARU
}

\author{
Ika Dewi Ana \\ Staf Pengajar Bagian Biomedika Kedokteran Gigi Universitas \\ Gadjah Mada dan Peneliti Rekayasa Jaringan \\ Judul Buku : Advances in Tissue Engineering \\ (Volume 1-Angiogenesis) \\ Editor \\ Penerbit : : Mary Ann Liebert Inc. \\ Tahun : 2010 \\ Tebal :298 halaman
}

Pada tahun 1997, dunia dikejutkan oleh suatu film dokumenter dalam program Tomorrow`s World serial BBC. Di dalam tayangan BBC menyiarkan tentang Vacanti Mouse, seekor tikus dengan daun telinga yang tumbuh di punggungnya. Sekalipun penelitian aslinya (seperti yang diakui oleh kelompok Cao dan Vacanti) yang berlangsung di laboratorium MIT (Massachussets Institute of Technology) tidak se-spektakuler seperti tayangan BBC, sejak saat itu istilah rekayasa jaringan (tissue engineering) menjadi istilah yang dikenal oleh jutaan masyarakat dunia. Harapan manusia akan adanya The Body Shop (yang setiap waktu dapat menyediakan organ tubuh pengganti) menuai titik terang.

\section{Dunia Baru Penyembuhan}

Dalam konteks ilmu pengetahuan dan klinis, impian manusia akan adanya “The Body Shop" telah diterjemahkan oleh dunia rekayasa jaringan. Rekayasa jaringan merupakan suatu terapi yang berbasis potensi penyembuhan alamiah (natural healing potential) pada pasien. Akan terapi, terapi tersebut dikenal sebagai terapi regenerasi jaringan dilakukan dengan cara menginduksi regenerasi jaringan atau organ menggunakan lingkungan buatan yang sesuai dengan kondisi biologis dan mampu memacu proliferasi dan diferensiasi sel ke arah regenerasi jaringan atau organ target. Ada 2 (dua) pendekatan dalam terapi regenerasi jaringan yang dimaksud.

Pendekatan pertama adalah transplantasi sel. Sel-sel dengan kemampuan proliferasi dan diferensiasi tinggi ditransplantasikan pada area jaringan tubuh yang rusak atau hilang, untuk menginduksi regenerasi jaringan. Sel-sel tersebut biasanya ditransplantasikan melalui metode injeksi bolus atau infus. Pendekatan ini memiliki beberapa kelemahan. Kelemahan tersebut antara lain adalah sedikitnya jumlah sel yang tertinggal di area transplantasi. Di samping itu, kemampuan sel untuk melakukan regenerasi tergolong rendah karena banyak 
sel yang mengalami ekskresi dan kematian. Untuk suatu proses regenerasi jaringan yang volumenya kecil, diperlukan sel dalam jumlah yang cukup banyak. Banyak menunjukkan bukti bahwa terapi dengan pendekatan transplantasi sel ini memiliki efikasi terapeutis yang rendah karena proporsi sel terbatas dan potensi proliferasi serta diferensiasi sel mengalami penurunan dalam fungsi waktu.

Pendekatan atau metode yang kedua adalah dengan memberikan lingkungan biologis yang sesuai untuk kehidupan sel-sel dan bersifat fungsional untuk sel. Lingkungan biologis tersebut akan menjadi perancah bagi sel-sel, juga menjadi pembawa molekul biosignal, sekaligus menjadi sumber makanan (nutrient) bagi sel. Lingkungan lokal yang secara biologis sesuai dengan kondisi in vivo akan memungkinkan sel-sel mengalami proliferasi dan diferensiasi yang laju dan arahnya dapat diatur. Perancah sebagai lingkungan biologis juga sekaligus dapat berfungsi menjadi pembawa faktorfaktor pertumbuhan, biomolekul (biosignaling molecule), dan protein. Teknologi pelepasan terkontrol (controlled release technology) juga akan memungkinkan biomolekul dan protein dilepaskan dengan kecepatan yang dapat diatur dan disesuaikan dengan kondisi aslinya. Dengan pendekatan ini, potensi biologis alamiah untuk regenerasi jaringan dapat ditingkatkan. Pendekatan kedua inilah yang dikenal sebagai rekayasa jaringan berbasis perancah (scaffold-based tissue engineering) yang dikemukakan oleh Joseph Langer dan Robert Vacanti (1993) dalam suatu artikel yang terbit di Majalah Science.

\section{Memicu Pertumbuhan Pembuluh Darah Baru}

Mengacu pada pendekatan kedua yang dikemukakan oleh Langer dan Vacanti (1993) itu, maka penting artinya mengoptimalkan trilogi sistem perancah-morfogen-sel dalam memacu pertumbuhan pembuluh darah baru. Mengapa? Jawabannya dikarenakan seluruh jaringan dalam tubuh memerlukan suplai darah yang akan membagikan oksigen dan nutrient (zat-zat makanan yang penting) serta mengusir karbon dioksida dan produk metabolism tubuh yang lain agar tidak bersarang dalam tubuh. Proses pertumbuhan jaringan pembuluh darah dikenal dengan istilah angiogenesis.

Pada masa embrio (tumbuh kembang janin), angiogenesis terjadi seiring dengan pertumbuhan jaringan parenkhimal. Difusi oksigen sejumlah $0,2 \mathrm{~mm}$ pada aliran darah manusia atau pada tekanan atmosfer akan mampu mempertahankan jaringan dalam kondisi baik. Tantangannya adalah bagaimana mengembalikan sistem tersebut lebih cepat pada jaringan hasil rekayasa (engineered tissue) setelah terjadinya implantasi. Inilah yang kemudian menjadi titik perhatian dalam dunia rekayasa jaringan.

Kontrol angiogenesis diakui telah menjadi aspek yang paling sulit dalam bidang rekayasa jaringan. Hal ini disebabkan oleh fungsi jaringan vaskular (pembuluh darah) yang di satu sisi harus mampu mempertahankan sel sampai ke tingkat mikrostruktural (dimensi mikro) serta mampu menumbuhkan perlekatan dengan arteri dan vena yang lebih besar (dimensi sentimeter), secara anatomis terdiri atas katup-katup dengan sistem transmisi elektris, dan variasi muskulatur yang kompleks, dan rumit. Pembuluh vena misalnya memiliki kekhasan pada desain katup-katupnya yang mampu melawan gravitasi sembari mengembalikan sirkulasi darah menuju jantung. Adapun pembuluh arteri memiliki kemampuan suplai darah yang istimewa karena mampu mengantar elemen dari satu kapiler ke kapiler lain yang dituju secara terprogram.

\section{Penelitian Mutakhir}

Pentingnya kontrol angiogenesis sebagai medan tantangan anatomis-fisiologis bagi perekayasa jaringan. Oleh sebab itulah, tidak salah bila Peter Johnson dan Antonios Mikos (keduanya editor jurnal terkenal Tissue Engineering) akhirnya memilih Angiogenesis 
sebagai serial pertama dalam suatu serial buku tentang perkembangan mutakhir rekayasa jaringan. Artikel-artikel yang dimuat dalam buku ini merupakan artikel terpilih terkait angiogenesis dalam dunia rekayasa jaringan yang terbit di jurnal Tissue Engineering sejak 2005 hingga 2009. Teknik pemilihan artikel dilakukan agar mampu menggambarkan secara menyeluruh perkembangan yang menyangkut prinsip dasar dan teknologinya.

Tampaknya buku ini cukup representatif untuk menelaah secara cepat perkembangan rekayasa jaringan dalam kaitannya dengan aspek angiogenesis. Johnson dan Mikos sepertinya telah memilah artikel-artikel tersebut berdasarkan indeks sitasi pada artikel dan distribusi geografis, sehingga mampu merangkum perkembangan penelitian di berbagai belahan dunia dengan cukup baik.

Johnson dan Mikos juga telah menyusun artikel-artikel yang diterbitkan dengan urutan yang baik mulai dari angiogenesis dan kaitannya dengan tekanan mekanis, beranjak ke peran obat dan faktor-faktor pertumbuhan dalam merangsang, memodulasi, dan memblok angiogenesis, beranjak lagi ke teknik kokultur sel dan sel punca dalam mekanisme kontrol angiogenesis. Buku ini juga memuat penelitian yang terkait dengan eksperimen yang menggambarkan keberhasilan formasi pembuluh mikro dan makro secara in vitro, meskipun dalam penelitian tersebut tampak bahwa pertumbuhan jaringan dengan koneksi optimal seperti aslinya masih menjadi tantangan utama.
Johnson dan Mikos yang telah bekerja bersama cukup lama juga telah memilih artikel yang menyangkut transplantasi jaringan mikrovaskular seperti eksperimen yang dilakukan oleh Shepherd dkk. Tahun 2007 dengan cara implantasi gel pada jaringan tikus yang mengalami infark myokardial. Telah dibuktikan oleh Shepherd dan kawan-kawan bahwa teknik tersebut tidak saja mampu mengembalikan perlekatan pembuluh, tetapi juga menyebabkan formasi baru arteri, vena, dan sistem kapiler dalam pembuluh darah pada jantung. Fungsi ventrikel kiri berkembang signifikan dengan teknik rekayasa jaringan dalam eksperimentasi tersebut.

\section{SIMPULAN}

Buku ini penting untuk dibaca mereka yang tertarik, bekerja, atau mendalami bidang rekayasa jaringan karena dapat merefleksikan dengan baik perkembangan teknik kontrol angiogenesis dalam bidang rekayasa jaringan. Buku ini sekaligus dapat menjadi alternatif rujukan yang cukup komprehensif untuk mempercepat perkembangan bidang rekayasa jaringan sehingga segera mampu menjawab harapan manusia akan The Body Shop yang lebih baik sehingga membantu menolong hidup mereka yang mengalami kerusakan atau kehilangan jaringan atau organ. 